\title{
Expression Pattern and Neurotrophic Role of the c-fms Proto-Oncogene M-CSF Receptor in Rodent Purkinje Cells
}

\author{
Shin-ichi Murase ${ }^{1}$ and Yokichi Hayashi ${ }^{2}$ \\ 1Department of Anatomy, Keio University School of Medicine, 35 Shinanomachi, Shinjuku-ku, Tokyo 160-8582, Japan, \\ and ${ }^{2}$ Department of Cell and Molecular Biology, Nagano College of Nursing, Akoho 1694, Komagane-shi, \\ Nagano 399-4117, Japan
}

To investigate whether the c-fms proto-oncogene plays a role in the CNS, we examined its expression in mouse brain. We found that c-fms-positive Purkinje cells first appeared in caudal cerebellum at postnatal day 0 (P0) arranged in a parasagittal manner, and most Purkinje cells gradually became positive by P6. This differential expression was not seen from P7 to adulthood, and the parasagittal pattern until P5 was different from those of L7, zebrins, and the integrin $\beta 1$ subunit. No neuronal expression of c-fms was found in the other brain regions examined. In both reeler and weaver mutant mice in the adult stage, all Purkinje cells were positive for c-fms as in the wildtype controls; however, the parasagittal bands of c-fmspositive Purkinje cells were observed even in the adult staggerer mutant. To check the neurotrophic effect of macrophage colony-stimulating factor (M-CSF), we immunostained cere- bella derived from osteopetrotic mutant mice, that is, those devoid of active M-CSF. We found that the number of calbindinpositive Purkinje cells in a given cerebellum began to decrease substantially during the initial 4-5 weeks of the postnatal period. In addition, cultured Purkinje cells were dependent on M-CSF for their survival. These data suggest that expression of the c-fms gene is intrinsically programmed in the Purkinje cells and never affected by the afferent synaptic input and that neuronal survival of Purkinje cells is dependent on M-CSF after weaning. Therefore, c-fms is considered to be a new developmental marker for Purkinje cells.

Key words: granule cell; parallel fiber; neurotrophin; cytokine; microglia; integrin; zebrin; parasagittal band; CSF-1; retinoic acid receptor-related orphan nuclear receptor $\alpha$
The c-fms proto-oncogene encodes the receptor for macrophage colony-stimulating factor (M-CSF) and is expressed in cells of the mononuclear phagocyte lineage (Nienhuis et al., 1985; Sariban et al., 1985; Sherr et al., 1985; Woolford et al., 1985; Rettenmier et al., 1986), in trophoblasts and decidual cells (Byrne et al., 1981; Muller et al., 1983a,b; Regenstreif and Rossant, 1989), and in B lymphocytes (Baker et al., 1993; Till et al., 1993). In the CNS, the expression of c-fms has been detected in microglia, astrocytes, and oligodendrocytes in vitro (Sawada et al., 1990, 1993); however, the precise cellular localization of c-fms in vivo is unknown. Recently, several studies have indicated that M-CSF is involved in neuronal development. The finding that M-CSF is produced by cultured cerebellar neurons raises the possibility that M-CSF may play a role in the cytokine network not only between glia but also between neurons (Nohava et al., 1992). Furthermore, M-CSF is reported to function as a growth factor in cases of tissue damage (Berezovskaya et al., 1996; Fedoroff et al., 1997). In the present paper, we investigated what kind of neurons express c-fms in the brains of developing and adult rodents by immunohistochemistry and in situ hybridization and found that Purkinje cells express c-fms. Lesion studies of climbing fibers and transplantation of cerebellar anlagen into the anterior eye chamber were performed

Received June 4, 1998; revised Sept. 21, 1998; accepted Oct. 1, 1998.

This research was supported by the Narishige Neuroscience Research Fund, the Keio Health Counseling Center, and the Ministry of Education, Science, Sports, and Culture of Japan.

Correspondence should be addressed to Dr. S. Murase, c/o Dr. Alan F. Horwitz, Department of Cell and Structural Biology, University of Illinois at UrbanaChampaign, B107 Chemical and Life Science Laboratory, 601 South Goodwin Avenue, Urbana, IL 61801.

Copyright (ㄷ 1998 Society for Neuroscience $\quad 0270-6474 / 98 / 1810481-12 \$ 05.00 / 0$ in an effort to determine whether the afferents to the Purkinje cells play a role in c-fms expression. Cerebellar mutant mice of three types, the reeler, staggerer, and weaver, and also osteopetrotic (op/op) mutant mice that are unable to produce active M-CSF (Wiktor-Jedrzejczak et al., 1990; Yoshida et al., 1990) were investigated to determine whether the Purkinje cells of these mutants express c-fms. Using a cell culture system, we confirmed that M-CSF possibly augments neurotrophic activities toward the Purkinje cells via c-fms.

\section{MATERIALS AND METHODS}

Chemicals and reagents. Polyclonal antibody against the cytoplasmic region of human c-fms protein (amino acid residues 952-971) and a peptide fragment corresponding to this region were purchased from Santa Cruz Biotechnology (Santa Cruz, CA). This antiserum is reported to recognize a single band of $150 \mathrm{kDa}$ (Santa Cruz Biotechnology data sheet). Another three preparations of polyclonal antibodies against c- $f m s$ (\#06-174, \#06-175, and \#06-176; Upstate Biotechnology, Lake Placid, NY) were used to confirm the central findings in this study. Anticalbindin monoclonal antibody was purchased from Sigma (Tokyo, Japan). Fluorescein isothiocyanate (FITC)-conjugated anti-rabbit IgG antibody and Texas Red-conjugated anti-mouse IgG antibody were purchased from Molecular Probes (Eugene, OR). Peroxidase-conjugated anti-rabbit IgG antibodies were from Medical and Biological Laboratories (Nagoya, Japan). Recombinant human M-CSF (rhM-CSF) was obtained from Morinaga Milk Industry (Zama, Japan).

Immunoperoxidase and immunofluorescence staining. For the experiments, 40 mice of the B6/C3Fe strain (CLEA Japan, Tokyo, Japan), including mutant mice (The Jackson Laboratory, Bar Harbor, ME), and 15 Fischer rats (CLEA Japan) were used according to the Animal Experimentation Guidelines of Keio University School of Medicine. They were anesthetized with ether and by intraperitoneal injection of $35 \%$ chloral hydrate $(0.5 \mathrm{ml} / \mathrm{kg})$ and were perfused through the aorta with fixatives of $4 \%$ paraformaldehyde and $0.1 \mathrm{M}$ phosphate buffer or acid 


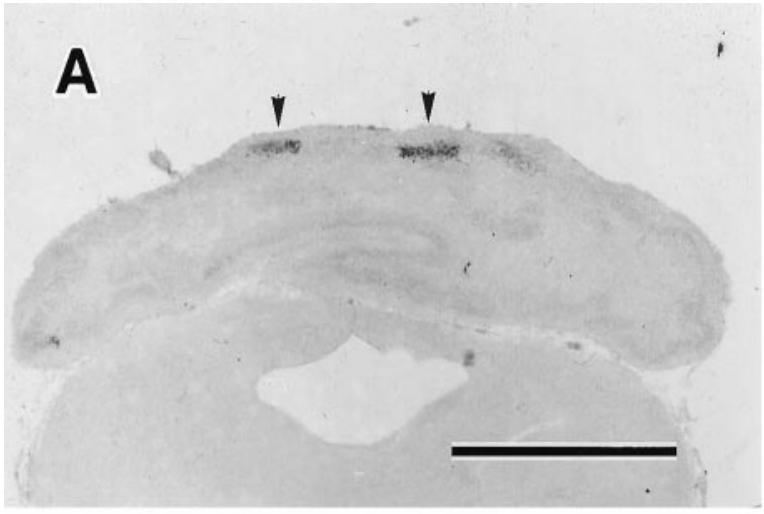

B
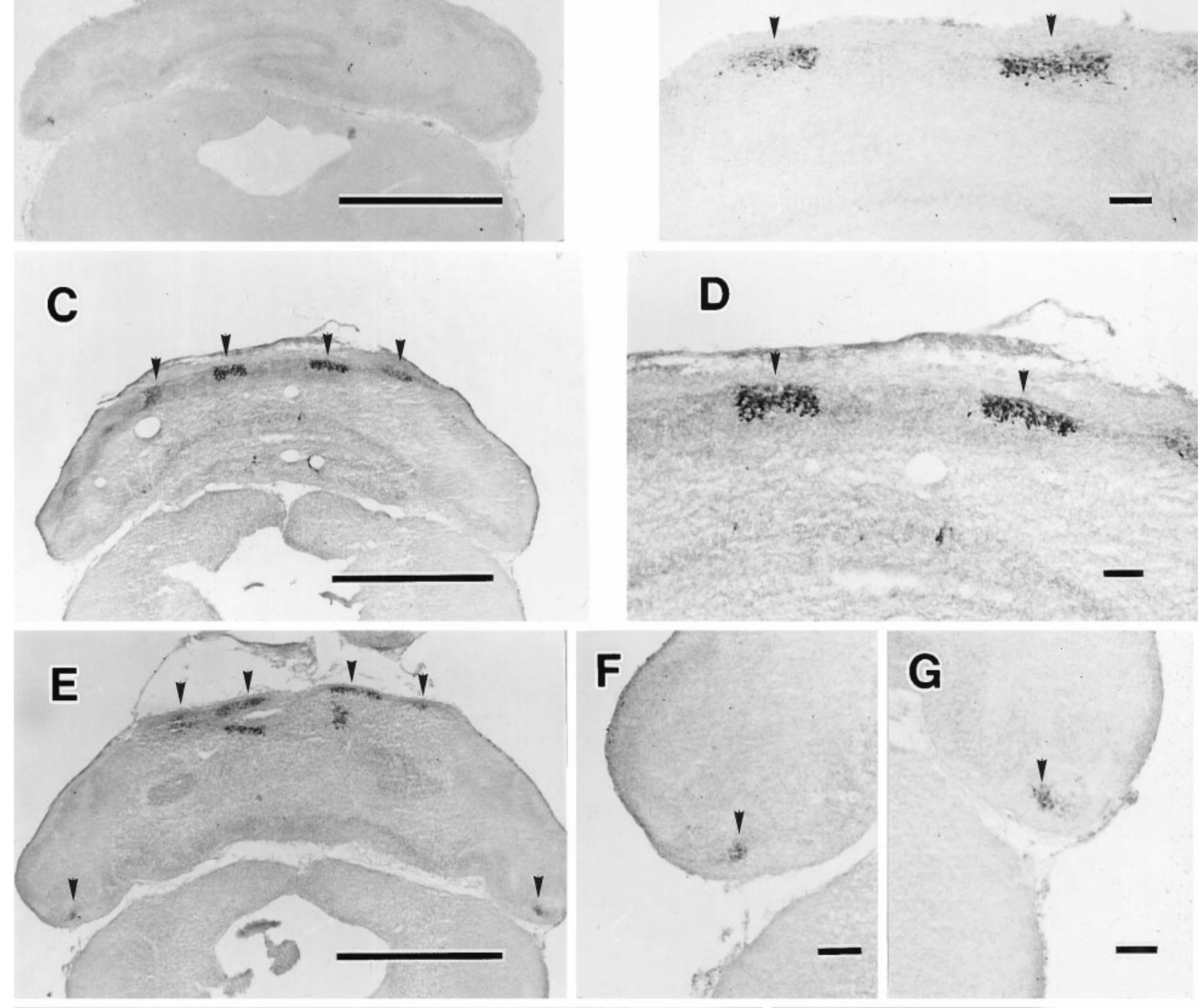

G
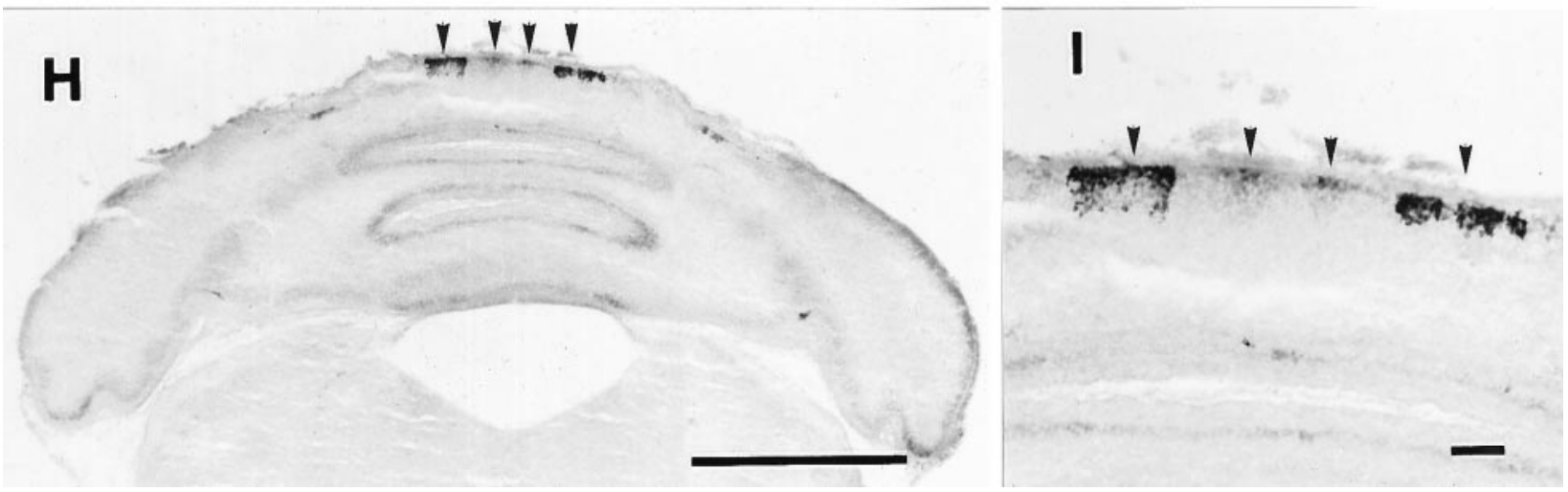

Figure 1. Postnatal mouse cerebella immunostained for c-fms. Horizontal sections through the cerebella were prepared and processed for immunostaining with anti-c-fms. A, c-fms-positive Purkinje cells first appeared as two discrete parasagittal bands (arrows) in the vermis at P0. B, High-power magnification of c-fms-positive Purkinje cells (arrows) in $A$ is shown. The c-fms-positive cells were arranged symmetrically. $C$, At P1, two additional bands appeared; thus the number of parasagittal bands in total was four (arrows). D, High-power magnification of c-fms-positive Purkinje cells (arrows) in $C$ is shown. E, From P1 onward, small clusters of c-fms-positive Purkinje cells (arrows) were found in the rostral cerebellum arranged in a symmetric manner. $F, G$, High-power magnification of c-fms-positive clusters (arrows) in the right lateral hemisphere $(F)$ and in the left lateral hemisphere $(G)$ is shown. $H$, At P2, four parasagittal bands (arrows) were found as shown in $C$ and $E$. I, High-power magnification of c-fos-positive Purkinje cells (arrows) in $H$ is shown. Scale bars: $A, C, E, H, 1 \mathrm{~mm} ; B, D, F, G, I, 100 \mu \mathrm{m}$. 
ethanol (5\% acetic acid $+95 \%$ ethanol). For immunoperoxidase staining, sections were treated with anti-c-fms antibody (1:200) for $42 \mathrm{hr}$ at $4^{\circ} \mathrm{C}$ and then incubated with peroxidase-conjugated goat anti-rabbit $\mathrm{IgG}$ (1:500) for $2 \mathrm{hr}$ at room temperature. The immune complexes on the sections were detected using a peroxidase substrate consisting of diaminobenzidine-tetrahydrochloride as described elsewhere (Murase and Hayashi, 1998a). For immunofluorescence staining, dissected brains were immersed in $20 \%$ sucrose and PBS, frozen in powdered dry ice, and embedded in Tissue-Tek O.C.T. compound (Miles, Elkhart, IN). Parasagittal or horizontal sections of brains $(20 \mu \mathrm{m})$ were cut on a cryostat and mounted on silane-coated slides for use in immunohistochemistry and in situ hybridization studies. The sections were incubated with the mixed solution of anti-c-fms antibody (1:200) and anti-calbindin monoclonal antibody $(1: 25,000)$ for $42 \mathrm{hr}$ at $4^{\circ} \mathrm{C}$. The anti-calbindin antibody was used to demonstrate the spatial relationships between calbindinpositive Purkinje cells and c-fms-positive Purkinje cells. After being rinsed to remove excess primary antibodies, the sections were incubated with the mixed solution of FITC-conjugated goat anti-rabbit IgG antibody (1:100) and Texas Red-conjugated goat anti-mouse IgG antibody (1:100) for $2 \mathrm{hr}$ at room temperature. The sections were rinsed in PBS, mounted in phosphate-buffered glycerol, and examined in a confocal laser microscope (MRC-600; Bio-Rad, Tokyo, Japan) with a dual excitation mode as described elsewhere (Murase and Hayashi, 1998b).

For immunostaining of cultured Purkinje cells, the same procedures were followed as described above.

In situ hybridization. The tissue sections were prepared as described above. Before hybridization with oligonucleotide probes, the sections were air-dried for $5 \mathrm{~min}$. After the sections were rinsed in PBS, depurination was performed for $20 \mathrm{~min}$ with $0.2 \mathrm{M} \mathrm{HCl}$ at room temperature; then the tissues were treated with proteinase $\mathrm{K}(25 \mu \mathrm{g} / \mathrm{ml})$ for $15 \mathrm{~min}$ at $37^{\circ} \mathrm{C}$. After post-fixation with $4 \%$ paraformaldehyde in PBS (5 min), the sections were immersed in $2 \mathrm{mg} / \mathrm{ml}$ glycine in PBS (30 min; twice). The sections were dehydrated with a series of solutions of increasing ethanol concentration and chloroform and finally were air-dried. An "antisense" oligonucleotide probe ( 48 mer) complementary to the sequence encoding bases 904-951 of c-fms mRNA was used for hybridization experiments (Berezovskaya et al., 1996). "Sense" strand probes with target sequences complementary to those of the antisense probes were used as a control for nonspecific hybrids. The oligonucleotides were chemically synthesized and HPLC-purified by the Bex Company (Tokyo, Japan). The oligoprobes $(0.2 \mu \mathrm{mol})$ were labeled at the $3^{\prime}$ end with digoxygenin.

Hybridization was performed at $37^{\circ} \mathrm{C}$ for $12 \mathrm{hr}$ with $0.1 \mu \mathrm{g} / \mathrm{ml}$ digoxygenin-oligonucleotide probe dissolved in the hybridization medium. After being washed at $37^{\circ} \mathrm{C}$ with $2 \times \mathrm{SSC}$ for $30 \mathrm{~min}, 1 \times \mathrm{SSC}$ for $30 \mathrm{~min}$, and $0.5 \times \mathrm{SSC}$ for $30 \mathrm{~min}$ twice, the sections were incubated in blocking solution (Boehringer Mannheim, Tokyo, Japan) for $1 \mathrm{hr}$. The sections were then treated for $2 \mathrm{hr}$ with alkaline phosphatase-labeled anti-digoxygenin antibody diluted (1:300) with the blocking solution. The alkaline phosphatase substrate 5-bromo-4-chloro-3-indolyl phosphate nitroblue tetrazolium chloride was used for color development, without counterstaining. All solutions used in this experiment were autoclaved in the presence of $0.1 \%$ diethylpyrocarbonate (Nacalai Tesque, Kyoto, Japan).

Destruction of climbing fibers. Five newborns and seven adult male mice 8 weeks old (B6/C3Fe strain) were used. Newborn mice were anesthetized with ether (Wako Chemical, Tokyo, Japan), and inferior cerebellar pedunculotomy was successively performed. The posterior part of the occipital bone was removed, and the posterior atlanto-occipital membrane and the dura mater were pierced and the inferior cerebellar peduncles were cut by inserting a capsulotomy knife into the fourth ventricle (Murase, 1995). A control adult without the pedunculotomy was used for anti-calbindin staining of the inferior olivary neurons.

Transplantation study. Cerebellar anlagen dissected from embryonic day 14 mice was transplanted into the anterior eye chamber of six adult mice (B6/C3Fe strain; 10 weeks old) using a microsyringe. Before the grafting surgery, the hosts were anesthetized with ether, and their eyes were treated topically with $1 \%$ atropine in $0.9 \%$ physiological saline to dilate the pupils. Subsequent immunohistochemical investigations were performed $30 \mathrm{~d}$ after grafting.

Mutant mice. The reeler, staggerer, and op/op mutations were each maintained in the hybrid $\mathrm{B} 6 \times \mathrm{C} 3 \mathrm{Fe}$ background, and the weaver mutation was maintained in the $\mathrm{B} 6 \times \mathrm{CBA}$ background. These heterozygous mutants were purchased from The Jackson Laboratory. Homozygous mutant mice were obtained by intercrossing fertile heterozygous mice. The homozygous cerebellar mutants were recognized by their smaller overall dimensions of the cerebella, especially at the midline, and by their smaller numbers of folia at postnatal day 6 (P6). At P24, the cerebellar ataxia of mutants enabled us to identify homozygotes. The $o p$ progeny were distinguishable from their normal siblings by a failure of eruption of incisors postnatally. These op/op mice were maintained on a diet of wet food purchased from CLEA Japan. Three reeler, three weaver, and three op mice of P24, P27, and P7 staggerer mice of P6, P12, P20, and P24 were used. Six control mice of the same age and strains of mutants were used according to the Animal Experimentation Guidelines of Keio University School of Medicine.

Culture of Purkinje cells. Primary culture of rat embryos (embryonic day 18) was performed according to the method described previously (Nakajima et al., 1993). Cell mixtures consisting of 70\% Purkinje cells were prepared as described elsewhere (Messer, 1989) and incubated in DMEM/Ham's F-12 containing 10\% FCS (DF-FCS) for $10 \mathrm{~d}$. This culture medium was then replaced with DMEM/Ham's F-12 supplemented with serum-free supplements (DF-SF) as described previously (Hayashi et al., 1994), containing various concentrations of rhM-CSF Some cultures were continuously maintained in DF-FCS without this replacement. These cultures were used as a control group and were regarded as showing $100 \%$ survival. After $7 \mathrm{~d}$ of incubation, the cultured cells were fixed and immunostained for calbindin to examine the neuronal survival rate of Purkinje cells. This was calculated as the ratio of the number of surviving Purkinje cells after a $7 \mathrm{~d}$ period of culture in DF-SF to that of Purkinje cells in the control group.

Statistical analysis. The ratio of surviving Purkinje cells under each culture condition was determined. Each experiment was done in quadruplicate. Each value represents the mean and $1 \mathrm{SD}$. Statistical analysis was performed by one-way ANOVA with Scheffé's multiple comparison procedure (significance with $p<0.05$ ).

\section{RESULTS}

\section{C-fms expression pattern in Purkinje cells}

Anti-c-fms immunostained the Purkinje cells, whereas the expression pattern of $\mathrm{c}-\mathrm{f} m \mathrm{~s}$ changed during postnatal stages. During the embryonic stage, the expression of c- $f m s$ was not observed (data not shown). At P0, when the c-fms-positive Purkinje cells first appeared in the caudal cerebellum, two symmetric bands arranged in a parasagittal manner were observed (Fig. 1A,B). During P1-P3, another two bands of c- $f m s$-positive Purkinje cells appeared (Fig. $1 C-I$ ). Furthermore, two small clusters of c-fmspositive Purkinje cells were also found consistently in the rostral cerebellum arranged in a symmetric manner (Fig. $1 E-G$ ). Thus, the number of distinct major bands became in total six during this postnatal period. From P4 to P5, the expression of c- $f m s$ spread to the rostral vermis and the hemispheres gradually (Fig. 2A,B), while the immunoreactivity of some Purkinje cells was still negative. The immunoreactivity was expressed evenly in most Purkinje cells at P6 (Fig. 2C), and subsequent to P7 and in the adult, c- $f m s$ was expressed in all of the Purkinje cells (data not shown). The immunoreactivity was localized not only in the cerebellar cortex but also in the deep cerebellar and vestibular nuclei, where Purkinje axons terminated and formed synapses (Fig. $2 F$ ). Double staining for c-fms and calbindin showed that Purkinje cells were the c-fms-positive structures, and calbindin-positive and c-fms-positive units were compatible in the cerebella (see Fig. 5). Other calbindin-positive neurons, such as hippocampal or cortical neurons, were not positive for c-fms (data not shown), and no immunopositive neurons were observed except for the Purkinje cells. However, the Purkinje axons in the granular layer were rarely stained c-fms-positive (Fig. 2D). This profile of c-fms immunoreactivity could not be reproduced when cerebellar slices were processed with normal rabbit serum instead of with anti-cfms antibodies (data not shown) or when primary antibody was preabsorbed with an excess amount of the c-fms C-terminal peptide (Fig. 2E).

Because c-fms expression is known to occur in microglia, 

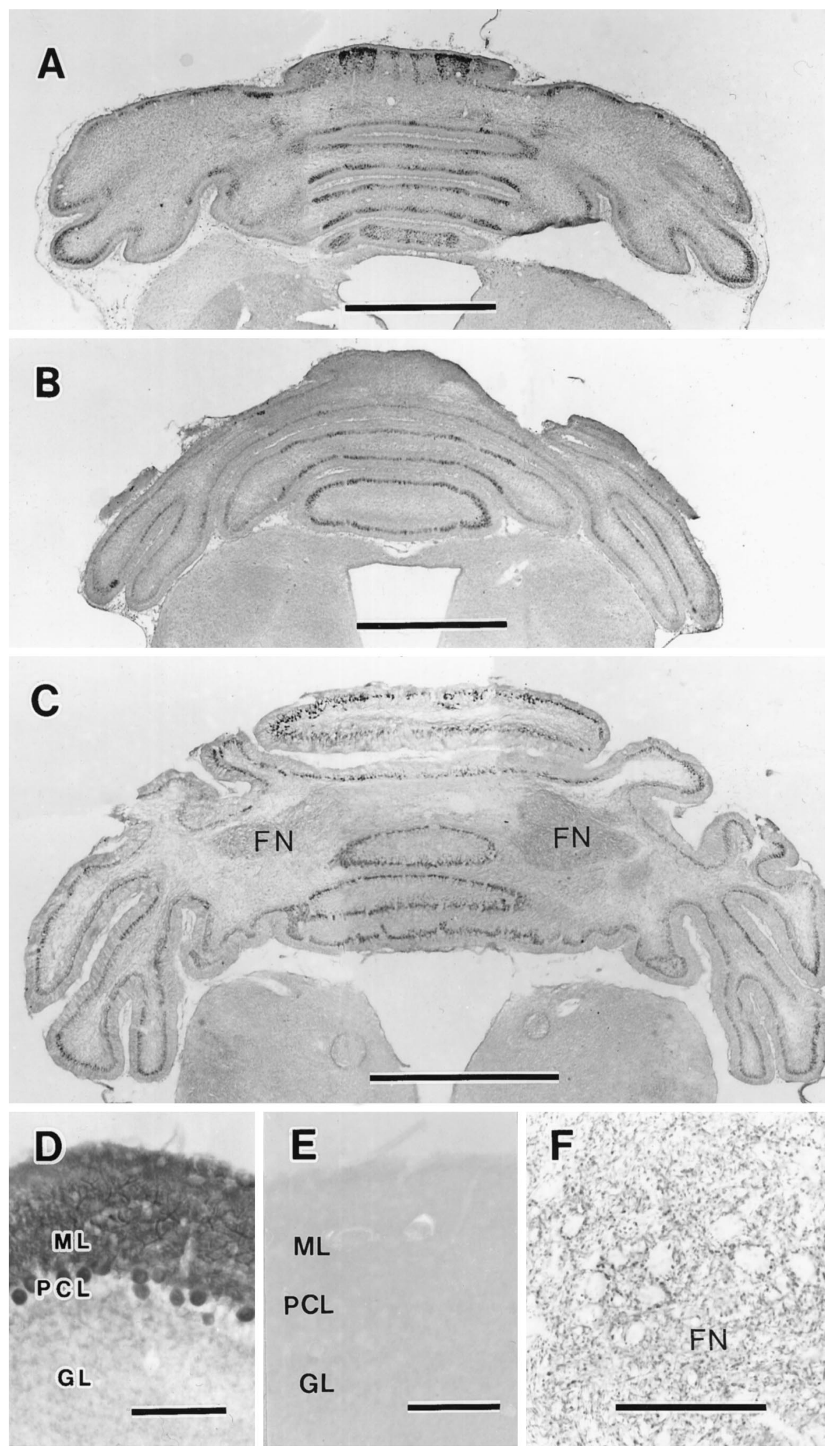


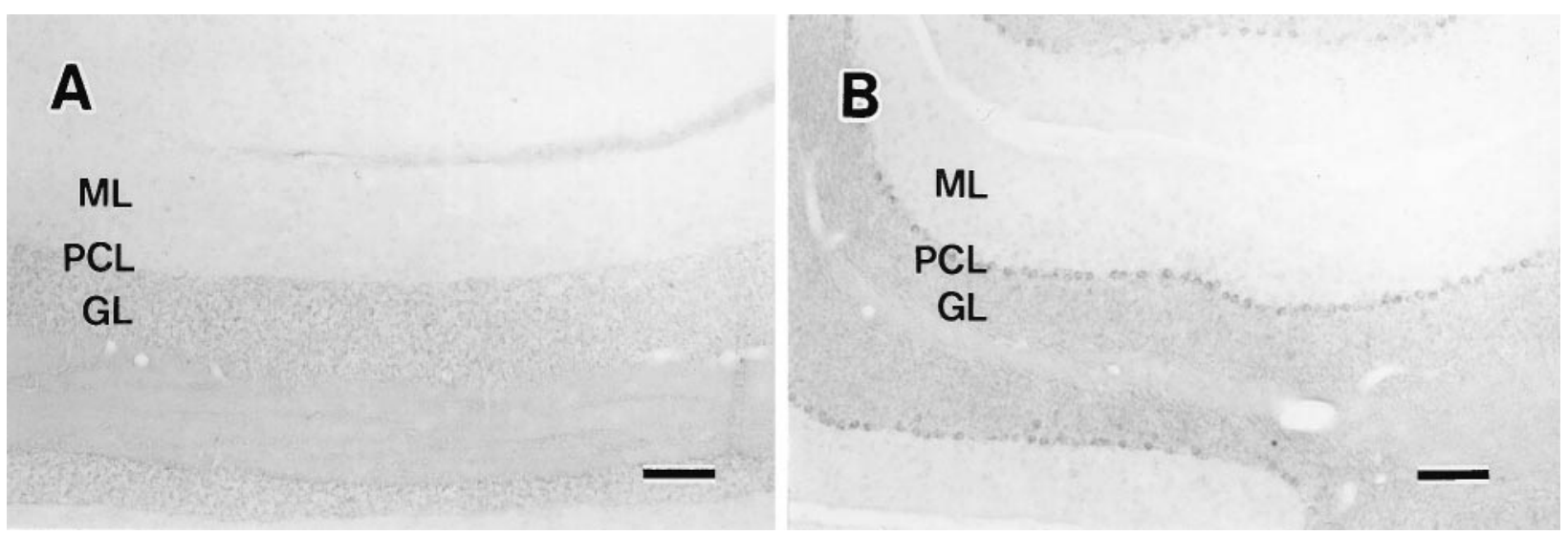

Figure 3. Expression of c-fms mRNA in the cerebellum of a P30 mouse. Digoxygenin-labeled oligonucleotide probes complementary to mouse c- $f m s$ were prepared. Mouse brains were hybridized with sense $(A)$ and antisense $(B)$ probes. Hybridization labeling specifically overlaid Purkinje cells $(B)$. The sense probe gave no signals in $A$. GL, Granular layer; $M L$, molecular layer; $P C L$, Purkinje cell layer. Scale bars, $100 \mu \mathrm{m}$.

astrocytes, and oligodendrocytes in vitro, we carefully examined its expression in these glial cells in vivo. However, c-fms immunoreactivity and mRNA expression were not observed in this study (data not shown).

\section{Expression of c-fms mRNA in Purkinje cells}

To confirm whether c-fms mRNA is expressed in the Purkinje cells, we performed in situ hybridization studies using oligonucleotide probes. The specificity of the antisense probes used in these in situ hybridization experiments was checked by using corresponding sense oligoprobes as negative controls. The sense probes gave dim signals of nonspecific background on the somata of Purkinje cells (Fig. $3 A$ ), whereas antisense probes resulted in strong distinct signals from Purkinje cells (Fig. $3 B$ ). Neither the dentate nucleus neurons nor other deep cerebellar neurons showed any positive signal (data not shown). Therefore, it seems that the positive immunoreactivity observed in the case of Purkinje cells was specific for the c-fms molecule.

\section{Lack of involvement of climbing fibers in the expression of c-fms in Purkinje cells}

The developmental expression of c- $f m s$ paralleled both Purkinje cell development and climbing fiber arborization. Thus, we speculated that these developmental events were not independent of each other. To test this hypothesis, we performed lesion studies using mice in which the inferior cerebellar peduncle was selectively cut. The inferior cerebellar pedunculotomy was performed at $\mathrm{P} 0$ or at the adult stage. The pedunculotomized neonatal mice were examined immunohistochemically at P3 and P25, and the climbing fiber-deafferented adults were examined $30 \mathrm{~d}$ later. To ascertain the complete destruction of the olivary neurons, we sliced and stained the medulla of the mice with anti-calbindin antibody (Fig. $4 A, B$ ). No changes in the differential expression of c-fms were found in these deafferented mice (Fig. 4C).

It was of interest to test whether or not the afferent inputs at prenatal stages may influence the expression of c-fms in the cerebellum. Thus, we next transplanted cerebellar anlagen from mice of embryonic day 14 into the anterior eye chamber of adult mice, in which no afferents are included (Altman and Bayer, 1978; Wassef et al., 1990), and c-fms was not expressed (Fig. 4D). Thirty days after grafting, the Purkinje cells in the grafted tissue were immunostained with anti-c-fms as well as with antibodies against calbindin, a typical marker of Purkinje cells. The Purkinje cells in the graft were not arranged in a single layer and rather showed a disorganized cytoarchitecture (Fig. 4E), which complicated our analysis of the Purkinje cell banding pattern. However, they remained c-fms-positive in their somata and dendrites (Fig. $4 F$ ). Thus, these results strongly imply that climbing fibers do not affect c-fms expression in developing Purkinje cells.

\section{c-fms expression in cerebellar and op/op mutant mice}

The expression of c-fms and calbindin in cerebella of reeler, staggerer, weaver, and op/op homozygotes was investigated by dual immunofluorescence microscopy. c-fms-positive Purkinje cells were found in the op/op (Fig. $5 A-C$ ), reeler (Fig. $5 D-F)$, and weaver (Fig. $5 G-I$ ) mutants. The Purkinje cells in these three mutants expressed both calbindin and c- $f m s$, so the distribution of these two antigens was the same. The staggerer Purkinje cells expressed calbindin; however, some of these cells did not express c-fms. Thus, the expression of c-fms among these cells was not consistent (Fig. $5 J-L$ ). These data indicate that the expression of c- $f m s$ is suppressed in some Purkinje cells of the staggerer mutants by intrinsic mechanisms.

Figure 2. Parasagittal bands of c-fms-positive mouse Purkinje cells. Horizontal sections through the cerebella were prepared and processed for immunostaining with anti-c-fms. A, c-fms-positive Purkinje cells were spread throughout the hemispheres at P3. The Purkinje cells in the intermediate zone gradually became c-fms-positive, so the clusters in the lateral hemispheres were not so distinct compared with those in the period of P1-P2. However, as shown in this figure, the Purkinje cells in the lateral hemispheres showed strong immunoreactivity. B, At P5, weakly stained Purkinje cells remained as parasagittal bands. $C$, At P6, most Purkinje cells expressed a substantial amount of c-fms, although the extent of immunostaining was somewhat weaker than that observed in other developmental stages. $D$, Higher magnification of the cerebellum at P30 is shown. Purkinje cells and their dendrites showed c-fms immunoreactivity. $E$, The cerebellum at P30 immunostained with anti-c-fms preabsorbed with antigen is shown. The c-fms immunoreactivity was completely absent when preabsorbed antibody was used. $F$, The cerebellar fastigial nucleus $(F N)$ at P30 is shown. Staining was found in the boutons surrounding the somata of deep cerebellar neurons of the fastigial nucleus. Because the deep neurons were c-fms-negative, they were unstained. $G L$, Granular layer; $M L$, molecular layer; $P C L$, Purkinje cell layer. Scale bars: $A-C, 1 \mathrm{~mm} ; D-F, 100 \mu \mathrm{m}$. 

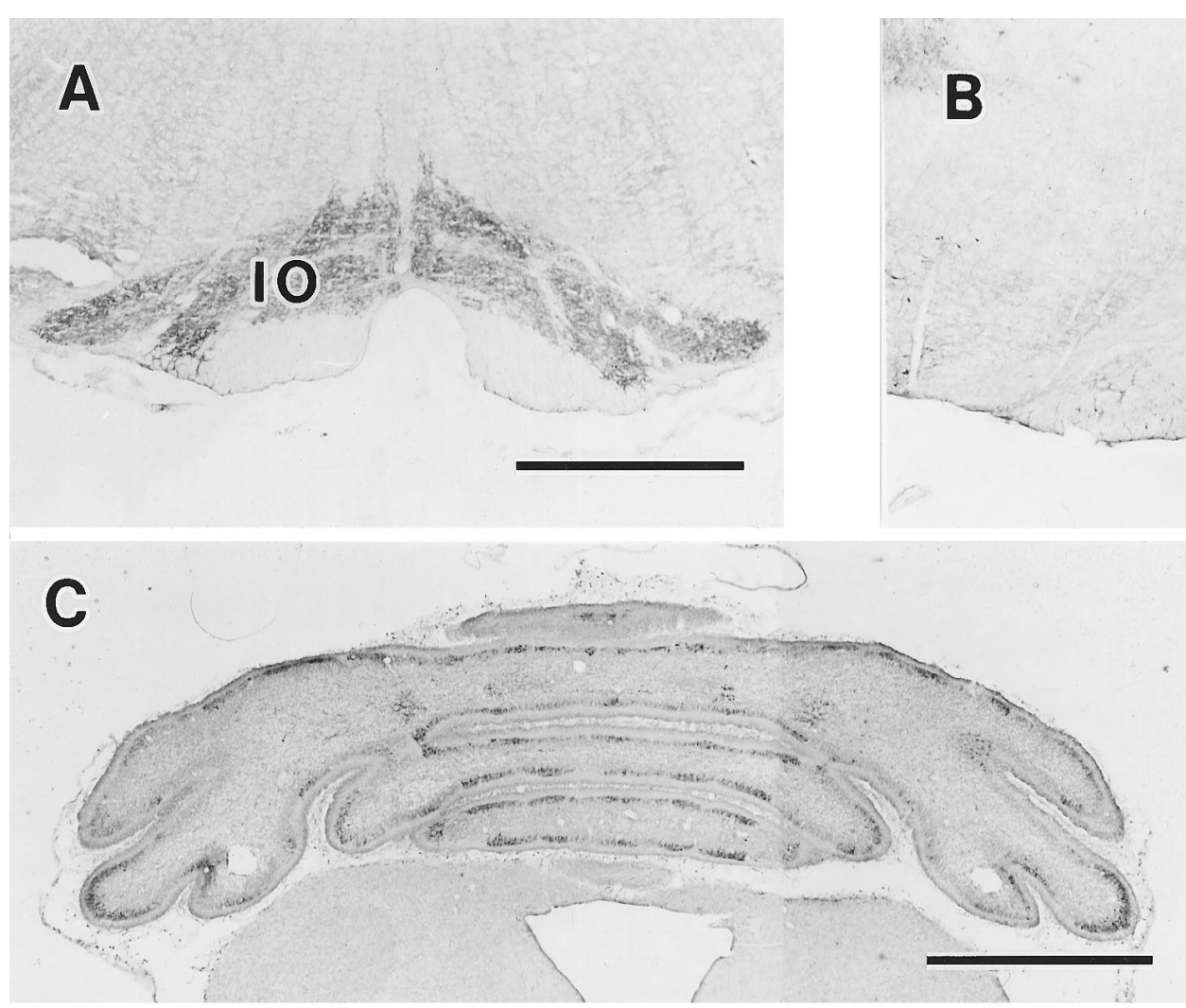

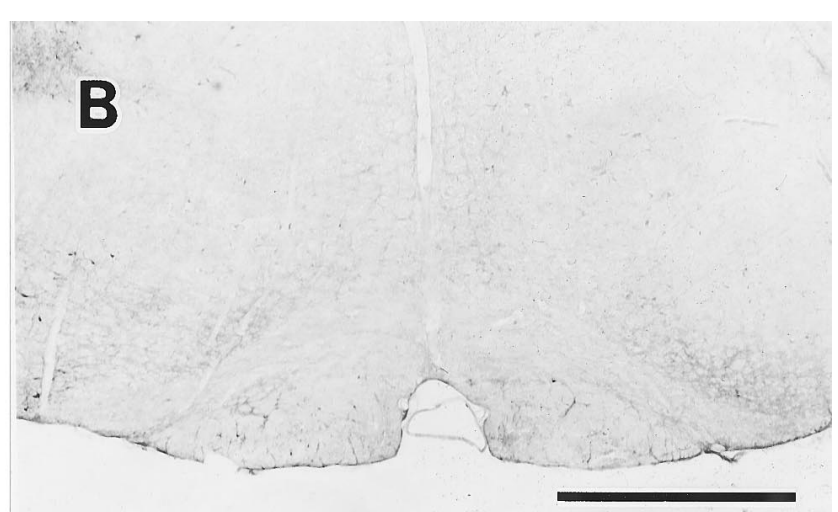

D

4v

NE
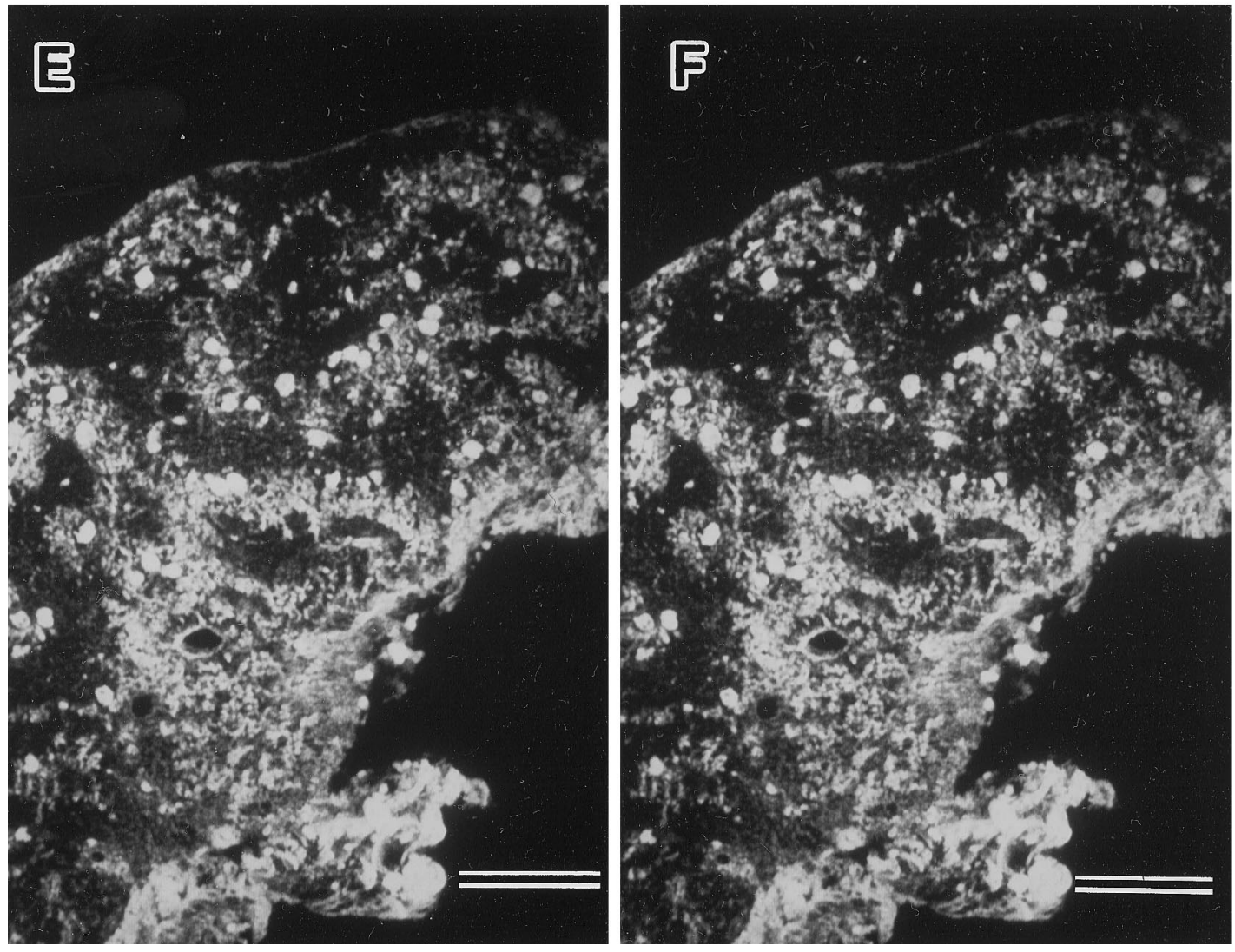

Figure 4. Effect of climbing fiber deafferentation on c-fms gene expression in Purkinje cells. After mice were pedunculotomized or after mice were subjected to cerebellar transplantation, cerebellar tissues were removed and processed for immunohistochemistry as described in Materials and Methods. $A, B$, Transverse sections of inferior olives $(I O)$ stained with anti-calbindin antibody are shown. $A$, IO prepared from an untreated normal adult mouse. $B$, IO from an adult mouse pedunculotomized at P0. Note the absence of the inferior olivary neurons in $B$. $C$, Immunohistochemistry of a horizontal section of climbing fiber-deficient cerebellum is shown. After inferior cerebellar peduncles were cut in a postnatal mouse at P0, the cerebellum was immunostained with anti-c-fms at P4. The destruction of climbing fibers did not alter the pattern of expression of c-fms (see Figs. 1, 2). D, Coronal (Figure legend continues) 
To investigate the possible mechanisms responsible for this finding concerning the staggerer Purkinje cells, we checked frontal and horizontal sections of staggerer cerebella in further detail. Because Purkinje cells in the staggerer display developmental delay or arrest (Yoon, 1976), we suspected that this may influence c-fms expression in these cells. This developmental delay or arrest influences integrin $\beta 1$ expression, which starts at P6 in normal pups, and the absence of integrin $\beta 1$ in the staggerer Purkinje cells suggested that they stop development earlier than P6 (Murase and Hayashi, 1996). Therefore, we suspected that the staggerer cerebella would show parasagittal bands of c-fmspositive Purkinje cells when sectioned in a horizontal or frontal plane, and our investigation revealed that c-fms-positive bands were evident even in the adult stage (Fig. 6). The c-fms-positive bands in the staggerer cerebella resembled those observed in the case of normal pups during P1-P3 (see Fig. $1 C, E, H$ ).

In addition to examining the staggerer mutant at P24, we also examined the staggerer at P6, P12, and P20 to test whether the cerebella from young staggerer mice expressed the parasagittal bands of c-fms-positive Purkinje cells. The bands were found in the staggerer cerebella examined, and they were similar to that of P24 (data not shown). Thus, most of the staggerer Purkinje cells were calbindin-positive but c-fms-negative, whereas some populations of Purkinje cells were positive for both calbindin and c-fms, and these cells were arranged to display the parasagittal bands when the staggerer cerebella were examined in horizontal or frontal planes.

\section{Possible functional role of M-CSF and c-fms in Purkinje cells}

The functional role of c- $f m s$ in the Purkinje cells was investigated using op/op mutants that could not produce active M-CSF. All Purkinje cells of op/op mutants showed both calbindin and c-fms immunoreactivity, as observed in the case of their normal littermates (Fig. $5 A-C$ ), but their numbers were reduced during the initial $4-5$ weeks in the postnatal period (Fig. 7). The distribution of the remaining Purkinje cells was random, showing no evident bands (data not shown). These data strongly suggest that the survival of Purkinje cells is dependent on M-CSF after weaning. To confirm this dependency, we prepared a mixed-cell suspension rich in Purkinje cells to be cultured with or without M-CSF. In the absence of M-CSF, most Purkinje cells died within a week, whereas most of them survived well when M-CSF was added (Fig. 8).

\section{DISCUSSION}

Glial cells were reported to express c-fms when they were cultured (Sawada et al., 1990, 1993), but we could not detect the expression of c-fms in glial cells in vivo. However, we have for the first time found that some Purkinje cells expressed c-fms in the course of cerebellar postnatal development and that the c-fmspositive Purkinje cells formed quite unique parasagittal bands during $\mathrm{P} 0-\mathrm{P} 6$.

Several antigens are known to show a transient banding pattern in embryonic or perinatal cerebella similar to that observed in the case of $\mathrm{c}-\mathrm{fms}$. Among these molecules, the following are included: cGMP-dependent protein kinase (cGK) (Wassef and Sotelo, 1984), calbindin (Wassef et al., 1985), Purkinje cell-specific glycoprotein (PSG) (Langley et al., 1982), PEP 19 (Wassef et al., 1992), and L7 (Oberdick et al., 1990, 1993). The expression of these molecules was first observed as parasagittal bands in the early developmental stage, and such banding patterns were not found during the first to second postnatal weeks, because all Purkinje cells began to express these markers evenly. Although the transient patterns were quite similar, the precise timing of onset of appearance and the expression patterns were different for markers (Wassef et al., 1992). For example, the onset of the appearance of immunoreactivity in Purkinje cells was observed at E16 in the case of calbindin, E17 in the case of cGK, around E20 in the case of PSG and PEP 19, and P0 in the case of c-fms. mRNA of L7 appeared between P4 and P8 and continued to be evident through to the adult stage (Oberdick et al., 1988). In transgenic mice carrying an L7- $\beta$-galactosidase fusion gene, expression of the transgene first appeared at E17 with four parasagittal bands of Purkinje cells, and the number of L7-positive Purkinje cells gradually increased during the first postnatal week. At P9, all Purkinje cells expressed the L7 gene (Oberdick et al., 1990, 1993; Smeyne et al., 1991). Therefore, the duration of appearance of transient bands in the case of c- $f m s$, from P0 to P5, was different from that of every other marker described above.

Subtle differences were confirmed by comparison of each spatiotemporal pattern of gene expression. The transient bands of c-fms-positive Purkinje cells were characterized as four main bands and two additional clusters in the lateral hemispheres (Fig. $1 E$ ), and the Purkinje cells of the midline were devoid of c-fms immunoreactivity during P0-P3. However, in the case of both cGK and PEP 19 the Purkinje cells of the midline were characterized as showing strong immunoreactivity at the time of onset of appearance of the transient bands (Wassef et al., 1992). The expression of calbindin was not detected at the midline at E16, the time of its onset; however, by E20 many Purkinje cells including those at the midline expressed calbindin. The banding patterns of calbindin and c- $f m s$ apparently differ from each other.

Other parasagittal bands were observed in postnatal or adult Purkinje cells. Zebrin I (Hawkes et al., 1985; Hawkes and Leclerc, 1986, 1987; Gravel et al., 1987; Leclerc et al., 1988), zebrin II (Brochu et al., 1990; Lannoo et al., 1991; Ahn et al., 1994), and integrin $\beta 1$ (Murase and Hayashi, 1996) were shown to reveal clear parasagittal bands composed of Purkinje cells from P6 onward. Zebrin- or integrin $\beta 1$ subunit-immunoreactive Purkinje cells first appeared caudally at P6, and most Purkinje cells gradually became positive by $\mathrm{P} 12$. The expression was then suppressed in some of these cells, so that the positive Purkinje cells in the adult were organized into parasagittal bands interposed by negative cells throughout the vermis and hemispheres. In contrast to $\mathrm{c}-\mathrm{fms}$ or other perinatal markers, zebrins or integrin $\beta 1$ showed parasagittal bands during the adult stage.

The developmental period, when the parasagittal bands

section of cerebellar anlagen immunostained with anti-c-fms is shown. Cerebellar anlagen was prepared from fetal mice at E14 and immunostained with anti-c- $f m s$ as described in Materials and Methods. No c- $f m s$ immunoreactivity was observed. $4 v$, Fourth ventricle; $N E$, neuroepithelium. $E, F$, Cerebellar anlagen of E14 was grafted into the anterior eye chamber of adult mice. Thirty days after grafting, the grafted tissue was dual-immunostained with anti-calbindin $(E)$ and anti-c-fms $(F)$. The cerebellar tissue in the anterior eye chamber contains calbindin-positive Purkinje cells, and the pattern of expression of c-fms and calbindin was similar. These calbindin-positive Purkinje cells formed clusters but were not arranged in a single layer. Scale bars: $A-C, 1 \mathrm{~mm} ; D-F, 100 \mu \mathrm{m}$. 

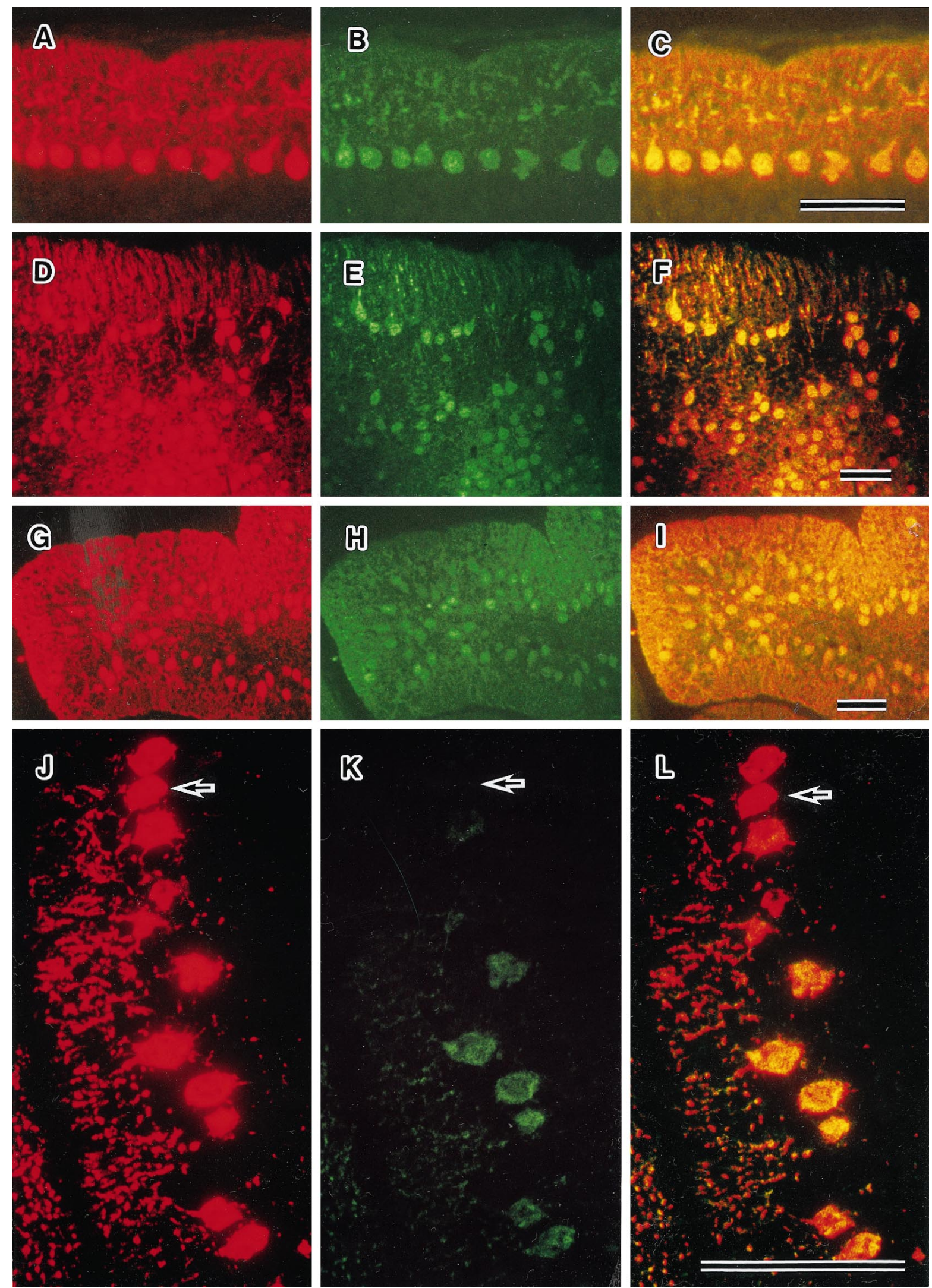

Figure 5. Dual immunofluorescence staining of parasagittal sections from mutant cerebella at P24 by anti-calbindin (red) and anti-c-fms (green) antibodies. The regions expressing both c-fms and calbindin are visualized as yellow regions. In osteopetrotic $(A-C)$, reeler $(D-F)$, and weaver $(G-I)$ mutant cerebella, the patterns of expression of c-fms and calbindin are similar. Displaced Purkinje cells in the reeler mutant express c-fms. Some of the staggerer Purkinje cells $(J-L)$ do not express c-fms (arrows). Scale bars, $100 \mu \mathrm{m}$. 


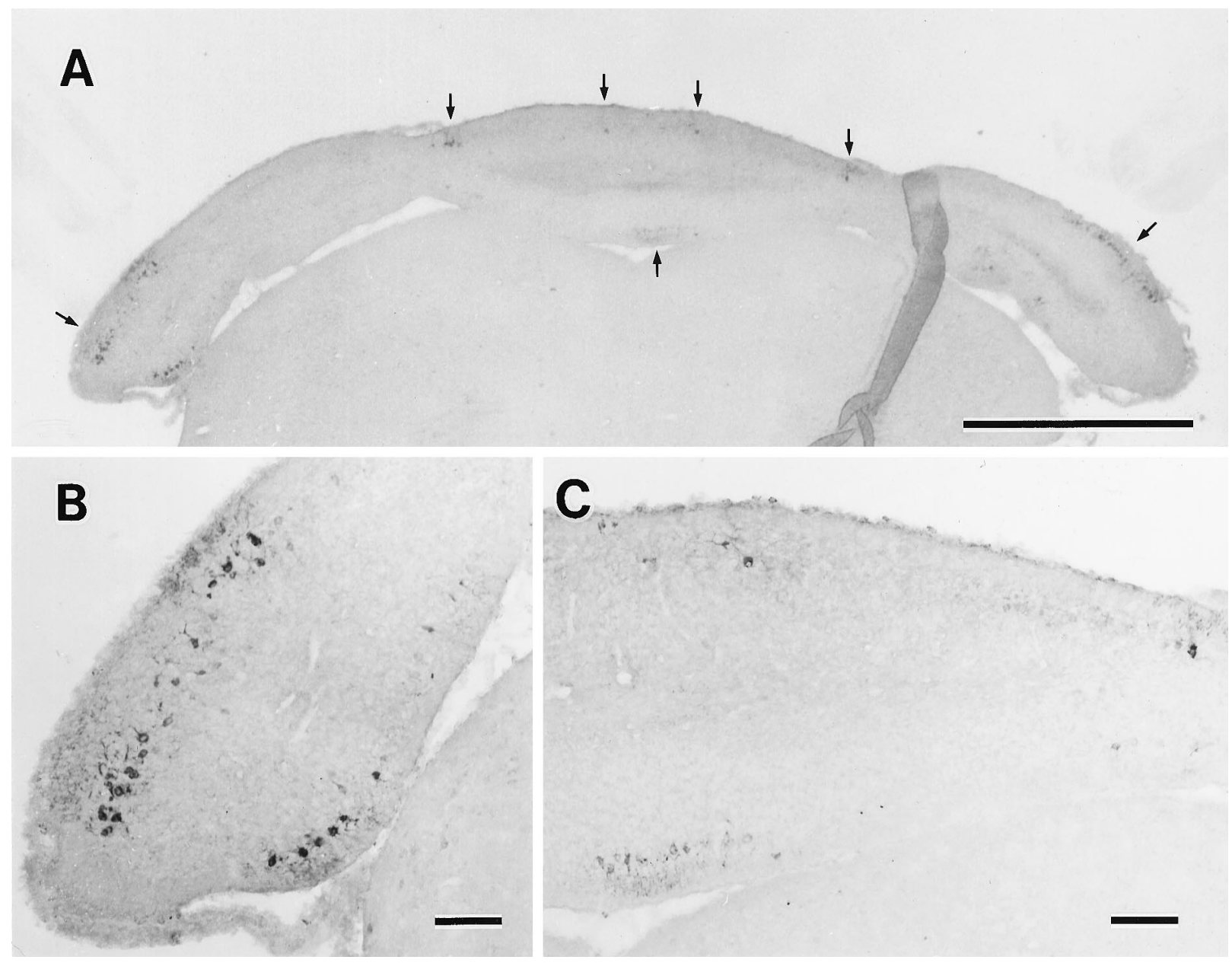

Figure 6. Parasagittal expression of c- $f m s$ in the staggerer Purkinje cells of P24. A, The selective expression of c-fms occurred in the vermis and the lateral hemispheres resembling the cerebella of wild-type mice during the period of P2-P3. The clusters of c-fms-positive Purkinje cells are indicated by arrows. $B$, High-power magnification of the lateral hemispheres of $A$ is shown. $C$, High-power magnification of the midvermis of $A$ is shown. Scale bars: $A, 1 \mathrm{~mm} ; B, C, 100 \mu \mathrm{m}$.

changed dramatically, corresponds to the period of synaptogenesis and dendritogenesis of Purkinje cells. We suspected that the synaptic input of climbing or parallel fibers might regulate c-fms expression in Purkinje cells. However, the pattern of expression of $\mathrm{c}-\mathrm{fms}$ in the cerebellum was not altered or disturbed by destruction of the climbing fibers, by the transplantation study, or by reeler or weaver mutations (D'Arcangelo et al., 1995; Patil et al., 1995). Thus, c-fms expression is independent of the synaptic input of developing climbing or parallel fibers.

The staggerer mutant, whose mutated locus contains the gene encoding $\operatorname{ROR} \alpha$ (retinoic acid receptor-related orphan nuclear receptor $\alpha$ ) (Hamilton et al., 1996), provides another line of evidence that Purkinje cells stimulate the autonomous expression of c-fms. The failure of interaction between $\operatorname{ROR} \alpha$ and the thyroid hormone signaling pathway might result in the immaturity of staggerer Purkinje cells, so these cells are almost devoid of spines on dendritic branchlets and have stunted dendrites (Landis and Sidman, 1978), and analysis of chimeric mice comparing the homozygote and wild type shows that the primary defect is localized to the Purkinje cells of the homozygote (Herrup and Mullen, 1979b, 1981).

Is the presence of c-fms bands in the staggerer caused by the developmental arrest or delay of the Purkinje cells? Yoon (1976) reported that the process of development of Purkinje cells as a whole was either delayed or arrested in the staggerer. We reported that staggerer Purkinje cells remained negative for the integrin $\beta 1$ subunit for their entire life (Murase and Hayashi, 1996). Because Purkinje cells of normal pups begin to express integrin $\beta 1$ at $\mathrm{P} 6$, the absence of integrin $\beta 1$ in the staggerer Purkinje cells suggests that the development of staggerer Purkinje cells is arrested before P6. During P1-P2, two symmetrical clusters of c-fms-positive Purkinje cells were observed in each lateral hemisphere, so three main c-fms positive bands were evident on each side of the midline. At P3, the Purkinje cells in the intermediate zone gradually became c-fms positive, so the clusters in the lateral hemispheres were not so distinct compared with those in the period of P1-P2. In the case of P3 cerebellum (Fig. 2A), the Purkinje cells in the lateral hemispheres showed strong immunoreactivity. The three bands on each side observed in the adult staggerer resembled those in the normal pups. Taken together, the c-fms-positive bands in the normal pups and their occurrence in the staggerer cerebella during P6-P24, it is plausible that the staggerer Purkinje cells cease their development at approximately P1-P3, resulting in their differential expression of c-fms.

The next question is whether the retention of the c-fms bands in the staggerer relates to regional differences in the number of 

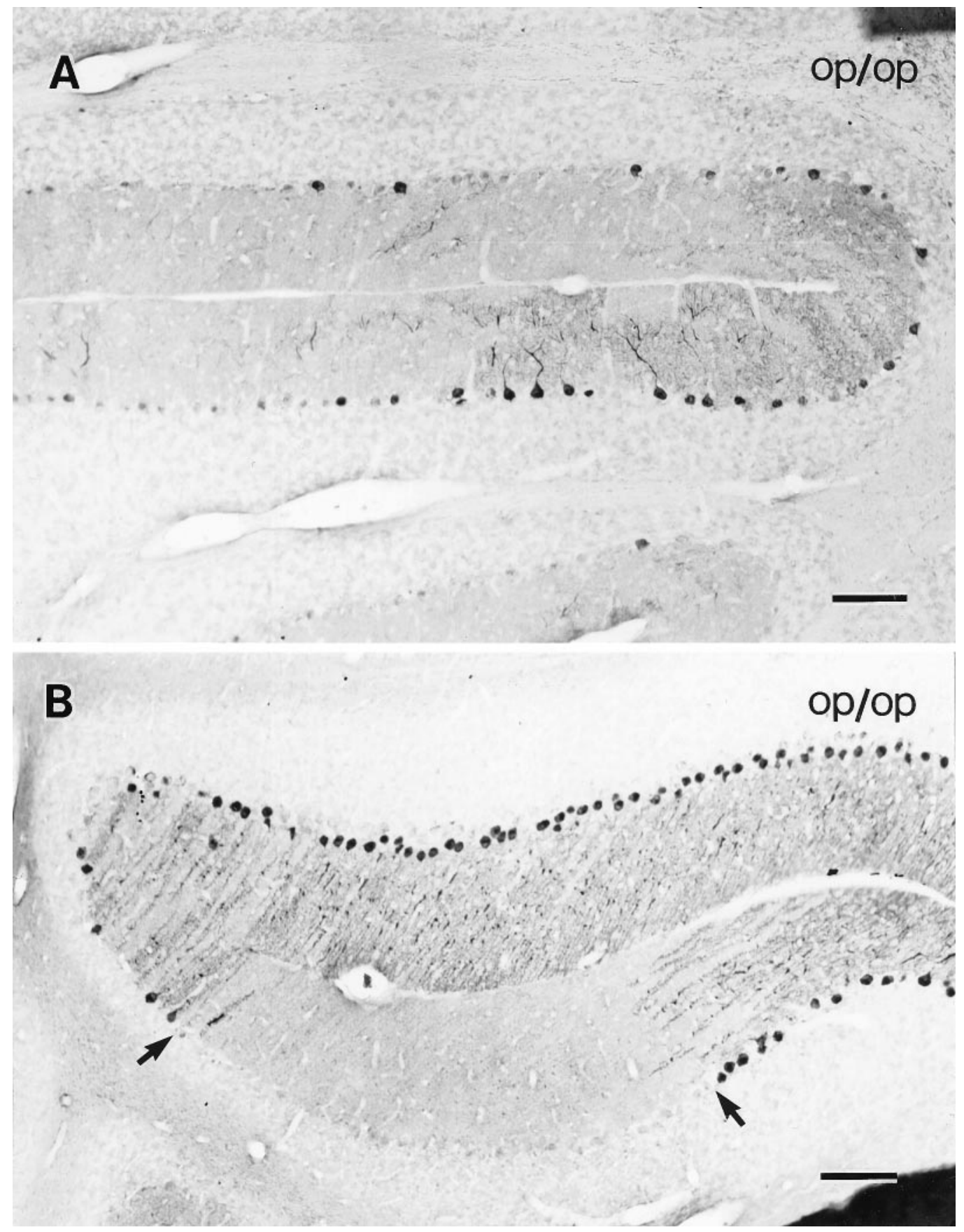

Figure 7. Partial absence of Purkinje cells in osteopetrotic mutant (op/op) cerebellum. Horizontal sections from mutant cerebellum of P27 were prepared and processed for immunostaining as described in Figure 1 using anti-calbindin antibody. $A$, Surviving Purkinje cells positive for calbindin were sporadically found. $B$, Massive loss of Purkinje cells is evident between the arrows. Scale bars, $100 \mu \mathrm{m}$.

surviving Purkinje cells in the staggerer, because M-CSF signaling via c-fms may function to promote neuronal survival. To test this, we surveyed the cerebella of op/op mutant mice that are devoid of active M-CSF. We found that the number of calbindinpositive Purkinje cells in a given cerebellum was reduced substantially during the initial 4-5 weeks of the postnatal period, and the remaining Purkinje cells were both c-fms- and calbindinpositive (Figs. 5, 6). These data strongly suggest that the survival of Purkinje cells is dependent on M-CSF after weaning, although the underlying molecular mechanism remains unclear.

As for the reduction of Purkinje cell number in the staggerer, they are reduced by 60-90\% (Herrup and Mullen, 1979a), and the reduction in number varies in severity along a mediolateral axis. The reduction in Purkinje cell number in the staggerer is most severe in the intermediate region and least severe in the lateral cerebella and at the midline (Herrup and Mullen, 1979a). If this reduction is caused by a direct effect of the $\operatorname{ROR} \alpha$ mutation, it seems likely that the regional variation would not appear. From our findings on c-fms expression and Purkinje cell loss in op/op mutants, we postulate that the regional variation might be attributable to the parasagittal expression of $\mathrm{c}-\mathrm{f} m \mathrm{~s}$ in the staggerer. We therefore suggest that the reduction in number of staggerer Pur- 


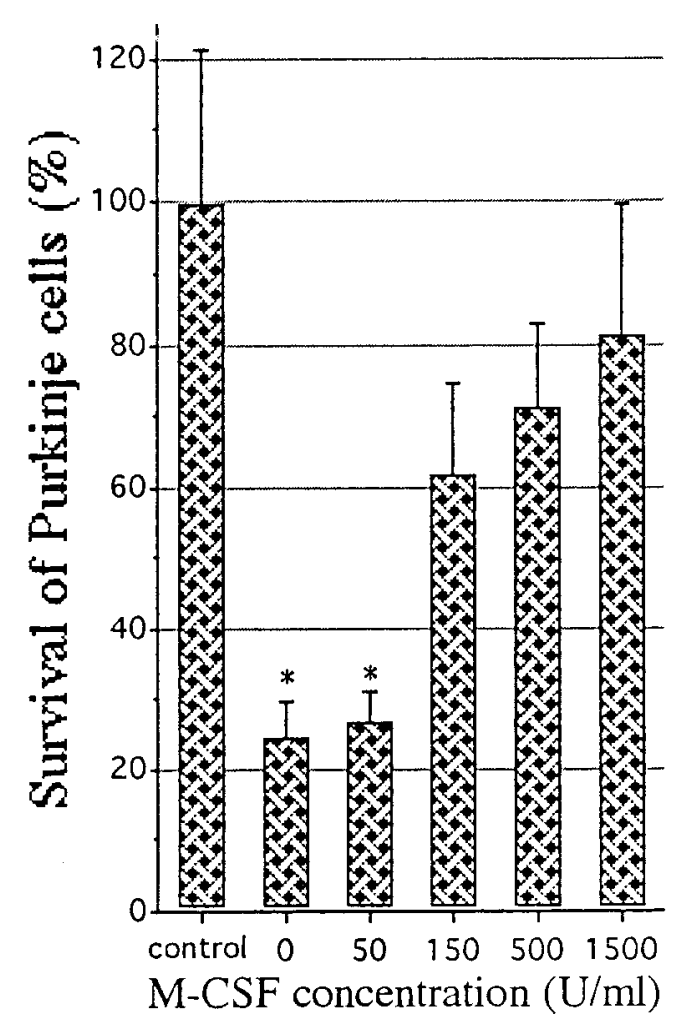

Figure 8. Enhancement of the survival of Purkinje cells by rhM-CSF. Samples rich in Purkinje cells were prepared from cerebellar cell suspensions of E18; then the cells were cultured in a serum-free medium with or without rhM-CSF for $7 \mathrm{~d}$. As a control group, Purkinje cells that had been cultured in serum-containing medium were used. The cells were then processed for immunostaining with anti-calbindin antibody to calculate the ratio of survival of the Purkinje cells compared with the control group. Each value represents the mean and $1 \mathrm{SD}$. Statistical analysis was performed by one-way ANOVA with Scheffé's multiple comparison procedure (significance with $p<0.05$ ). The control group differs from every other group. The groups with asterisks do not differ from each other, nor do the nonmarked groups, but in all other comparisons the differences are significant.

kinje cells might be triggered by the fact that most of them fail to express c-fms because of their developmental arrest during P1P3. The restricted expression of c-fms might still allow the Purkinje cells in the midvermis and lateral hemispheres to survive.

It remains unanswered why many Purkinje cells survive in the op/op cerebella. One plausible explanation is that M-CSF has a neurotrophic effect after weaning, and until then other neurotrophic factors might nurture the Purkinje cells. This idea is partly supported by the results that cultured Purkinje cells show more survival activity in the presence of M-CSF than in its absence (Fig. 8). Therefore, the decreased number of op/op Purkinje cells in postnatal cerebellum is possibly caused by a deficiency of $\mathrm{M}-\mathrm{CSF}$ in a critical period after weaning. However, we could not observe the complete degeneration of Purkinje cells in the living op/op mice, because these mice usually die during P28-P30. Further studies would be indispensable to determine whether ectopic M-CSF is effective to inhibit the decrease in Purkinje cell numbers in op/op mice.

\section{REFERENCES}

Ahn AH, Dziennis S, Hawkes R, Herrup K (1994) The cloning of zebrin II reveals its identity with aldolase C. Development 120:2081-2090. Altman J, Bayer SA (1978) Prenatal development of the cerebellar sys- tem in the rat. I. Cytogenesis and histogenesis of the deep cerebellar nuclei and the cortex of the cerebellum. J Comp Neurol 179:23-48.

Baker AH, Ridge SA, Hoy T, Cachia PG, Culligan D, Baines P, Whittaker JA, Jacobs A, Padua RA (1993) Expression of the colonystimulating factor 1 receptor in B lymphocytes. Oncogene 8:371-378.

Berezovskaya O, Maysinger D, Fedoroff S (1996) Colony stimulating factor-1 potentiates neuronal survival in cerebral cortex ischemic lesion. Acta Neuropathol (Berl) 92:479-486.

Brochu G, Maler L, Hawkes R (1990) Zebrin II: a polypeptide antigen expressed selectively by Purkinje cells reveals compartments in rat and fish cerebellum. J Comp Neurol 291:538-552.

Byrne PV, Guilbert LJ, Stanley ER (1981) Distribution of cells bearing receptors for a colony-stimulating factor (CSF-1) in murine tissues. J Cell Biol 91:848-853.

D'Arcangelo G, Miao GG, Chen SC, Soares HD, Morgan JI, Curran T (1995) A protein related to extracellular matrix proteins deleted in the mouse mutant reeler. Nature 374:719-723.

Fedoroff S, Berezovskaya O, Maysinger D (1997) Role of colony stimulating factor-1 in brain damage caused by ischemia. Neurosci Biobehav Rev 21:187-191.

Gravel C, Eisenman LM, Sasseville R, Hawkes R (1987) Parasagittal organization of the rat cerebellar cortex: direct correlation between antigenic Purkinje cell bands revealed by mabQ113 and the organization of the olivocerebellar projection. J Comp Neurol 265:294-310.

Hamilton BA, Frankel WN, Kerrebrock AW, Hawkins TL, FitzHugh W, Kusumi K, Russell LB, Mueller KL, van Berkel V, Birren BW, Kruglyak L, Lander ES (1996) Disruption of the nuclear hormone receptor ROR $\alpha$ in staggerer mice. Nature 379:736-739.

Hawkes R, Leclerc N (1986) Immunocytochemical demonstration of topographic ordering of Purkinje cell axon terminals in the fastigial nuclei of the rat. J Comp Neurol 244:481-491.

Hawkes R, Leclerc N (1987) Antigenic map of the rat cerebellar cortex: the distribution of parasagittal bands as revealed by monoclonal antiPurkinje cell antibody mabQ113. J Comp Neurol 256:29-41.

Hawkes R, Colonnier M, Leclerc N (1985) Monoclonal antibodies reveal sagittal banding in the rodent cerebellar cortex. Brain Res 333:359-365.

Hayashi Y, Kawashima K, Ohta J, Nakajima M, Kawashima T, Yoshikawa K (1994) Alzheimer amyloid protein precursor enhances proliferation of neural stem cells from rat brain. Biochem Biophys Res Commun 205:936-943.

Herrup K, Mullen RJ (1979a) Regional variation and absence of large neurons in the cerebellum of the staggerer mouse. Brain Res 172:1-12.

Herrup K, Mullen RJ (1979b) Staggerer chimeras: intrinsic nature of Purkinje cell defects and implications for normal cerebellar development. Brain Res 178:443-457.

Herrup K, Mullen RJ (1981) Role of the Staggerer gene in determining Purkinje cell number in the cerebellar cortex of mouse chimeras. Brain Res 227:475-485.

Landis DM, Sidman RL (1978) Electron microscopic analysis of postnatal histogenesis in the cerebellar cortex of staggerer mutant mice. J Comp Neurol 179:831-863.

Langley OK, Reeber A, Vincendon G, Zanetta JP (1982) Fine structural localization of a new Purkinje cell-specific glycoprotein subunit: immunoelectron microscopical study. J Comp Neurol 208:335-344.

Lannoo MJ, Brochu G, Maler L, Hawkes R (1991) Zebrin II immunoreactivity in the rat and in the weakly electric teleost Eigenmannia (gymnotiformes) reveals three modes of Purkinje cell development. J Comp Neurol 310:215-233.

Leclerc N, Gravel C, Hawkes R (1988) Development of parasagittal zonation in the rat cerebellar cortex: mabQ113 antigenic bands are created postnatally by the suppression of antigen expression in a subset of Purkinje cells. J Comp Neurol 273:399-420.

Messer A (1989) Primary cultures of cerebellar Purkinje cells. In: Manual of the nervous system (Shahar A et al., eds), pp 198-199. New York: Liss.

Muller R, Slamon DJ, Adamson ED, Tremblay JM, Muller D, Cline MJ, Verma IM (1983a) Transcription of c-onc genes c-rasKi and c-fms during mouse development. Mol Cell Biol 3:1062-1069.

Muller R, Tremblay JM, Adamson ED, Verma IM (1983b) Tissue and cell type-specific expression of two human c-onc genes. Nature 304:454-456.

Murase S (1995) Climbing fibre destruction triggers mossy fibre sprouting in adult rat cerebellum. NeuroReport 6:777-781.

Murase S, Hayashi Y (1996) Expression pattern of integrin $\beta 1$ subunit in 
Purkinje cells of rat and cerebellar mutant mice. J Comp Neurol 375:225-237.

Murase S, Hayashi Y (1998a) Integrin $\alpha 1$ localization in murine central and peripheral nervous system. J Comp Neurol 395:166-176.

Murase S, Hayashi Y (1998b) Concomitant expression of genes encoding integrin $\alpha \mathrm{v} \beta 5$ heterodimer and vitronectin in growing parallel fibers of postnatal rat cerebellum: a possible role as mediators of parallel fiber elongation. J Comp Neurol 397:199-212.

Nakajima M, Furukawa S, Hayashi K, Kawashima T, Hayashi Y (1993) Age-dependent survival-promoting activity of vitamin K on cultured CNS neurons. Dev Brain Res 73:17-23.

Nienhuis AW, Bunn HF, Turner PH, Gopal TV, Nash WG, O’Brien SJ, Sherr CJ (1985) Expression of the human c-fms proto-oncogene in hematopoietic cells and its deletion in the 5q- syndrome. Cell 42:421-428.

Nohava K, Malipiero U, Frei K, Fontana A (1992) Neurons and neuroblastoma as a source of macrophage colony-stimulating factor. Eur J Immunol 22:2539-2545.

Oberdick J, Levinthal F, Levinthal C (1988) A Purkinje cell differentiation marker shows a partial DNA sequence homology to the cellular sis/PDGF2 gene. Neuron [Erratum (1989) 3:following 385] 1:367-376.

Oberdick J, Smeyne RJ, Mann JR, Zackson S, Morgan JI (1990) A promoter that drives transgene expression in cerebellar Purkinje and retinal bipolar neurons. Science 248:223-226.

Oberdick J, Schilling K, Smeyne RJ, Corbin JG, Bocchiaro C, Morgan JI (1993) Control of segment-like patterns of gene expression in the mouse cerebellum. Neuron 10:1007-1018.

Patil N, Cox DR, Bhat D, Faham M, Myers RM, Peterson AS (1995) A potassium channel mutation in weaver mice implicates membrane excitability in granule cell differentiation. Nat Genet 11:126-129.

Regenstreif LJ, Rossant J (1989) Expression of the c-fms protooncogene and of the cytokine, CSF-1, during mouse embryogenesis. Dev Biol 133:284-294.

Rettenmier CW, Sacca R, Furman WL, Roussel MF, Holt JT, Nienhuis AW, Stanley ER, Sherr CJ (1986) Expression of the human c-fms proto-oncogene product (colony-stimulating factor-1 receptor) on peripheral blood mononuclear cells and choriocarcinoma cell lines. J Clin Invest 77:1740-1746.

Sariban E, Mitchell T, Kufe D (1985) Expression of the c-fms protooncogene during human monocytic differentiation. Nature 316:64-66.

Sawada M, Suzumura A, Yamamoto H, Marunouchi T (1990) Activation and proliferation of the isolated microglia by colony stimulating factor-1 and possible involvement of protein kinase C. Brain Res 509:119-124.

Sawada M, Itoh Y, Suzumura A, Marunouchi T (1993) Expression of cytokine receptors in cultured neuronal and glial cells. Neurosci Lett 160:131-134.

Sherr CJ, Rettenmier CW, Sacca R, Roussel MF, Look AT, Stanley ER (1985) The c-fms proto-oncogene product is related to the receptor for the mononuclear phagocyte growth factor, CSF-1. Cell 41:665-676.

Smeyne RJ, Oberdick J, Schilling K, Berrebi AS, Mugnaini E, Morgan JI (1991) Dynamic organization of developing Purkinje cells revealed by transgene expression. Science 254:719-721.

Till KJ, Lopez A, Slupsky J, Cawley JC (1993) c-fms protein expression by B-cells, with particular reference to the hairy cells of hairy-cell leukaemia. Br J Haematol 83:223-231.

Wassef M, Sotelo C (1984) Asynchrony in the expression of guanosine $3^{\prime}: 5^{\prime}$-phosphate-dependent protein kinase by clusters of Purkinje cells during the perinatal development of rat cerebellum. Neuroscience 13:1217-1241.

Wassef M, Zanetta JP, Brehier A, Sotelo C (1985) Transient biochemical compartmentalization of Purkinje cells during early cerebellar development. Dev Biol 111:129-137.

Wassef M, Sotelo C, Thomasset M, Granholm AC, Leclerc N, Rafrafi J, Hawkes R (1990) Expression of compartmentation antigen zebrin I in cerebellar transplants. J Comp Neurol 294:223-234.

Wassef M, Angaut P, Arsenio-Nunes L, Bourrat F, Sotelo C (1992) Purkinje cell heterogeneity: its role in organizing the topography of the cerebellar cortex connections. In: The cerebellum revisited (Llinás R, Sotelo C, eds), pp 5-21. New York: Springer.

Wiktor-Jedrzejczak W, Bartocci A, Ferrante Jr A, Ahmed-Ansari A, Sell KW, Pollard JW, Stanley ER (1990) Total absence of colonystimulating factor 1 in the macrophage-deficient osteopetrotic (op/op) mouse. Proc Natl Acad Sci USA [Erratum (1991) 88:5937] $87: 4828-4832$.

Woolford J, Rothwell V, Rohrschneider L (1985) Characterization of the human c-fms gene product and its expression in cells of the monocyte-macrophage lineage. Mol Cell Biol 5:3458-3466.

Yoon CH (1976) Pleiotropic effect of the staggerer gene. Brain Res 109:206-215.

Yoshida H, Hayashi S, Kunisada T, Ogawa M, Nishikawa S, Okamura H, Sudo T, Shultz LD, Nishikawa S (1990) The murine mutation osteopetrosis is in the coding region of the macrophage colony stimulating factor gene. Nature 345:442-444. 